\title{
Behavioral components of feeding selectivity of the heterotrophic dinoflagellate Protoperidinium pellucidum
}

\author{
Edward J. Buskey* \\ Marine Science Institute, The University of Texas at Austin, 750 Channelview Drive, Port Aransas, Texas 78373, USA
}

\begin{abstract}
Protoperidinium pellucidum is a pallium feeding heterotrophic dinoflagellate that captures phytoplankton cells individually and digests them externally. In laboratory cultures, $P$. pellucidum feeds on a variety of diatom species and a limited number of dinoflagellate species, and grows more rapidiy on diatoms than dinoflagellates. When offered food in mixed assemblages, it feeds selectively on diatoms over dınoflagellates, and selects between diatom species. Selectivity between different diatom species does not appear to be related to size, and size alone does not explain the low selectivity for dinoflagellates. Computerized motion analysis studies of swimming behavior reveal that $P$. pellucidum appears to use chemoreception as the major sensory mode to detect and locate food. When $P$. pellucidum passes near a food cell it circles around the cell several times before attaching to the food particle, apparently using chemoreception to judge the location of the cell. Detalled behavioral observations reveal that $P$. pellucidum sometimes loses contact with motile dinoflagellate cells before the capture occurs; such losses were not observed with diatoms. In addition, motile dinoflagellate prey often escape after initial capture, their swimming behavior causing the capture filament to break before the cell can be engulfed by the pallium of $P$. pellucidum; loss of a diatom after attachment was extremely rare. Feeding selectivity may be explained in part by the nature of the chemosensory signals given off by dufferent prey types, and therefore the distance at which $P$. pellucidum can detect food, and in part by the lower capture success of $P$. pellucidum with motile prey.
\end{abstract}

KEY WORDS: Heterotrophic dinoflagellates $\cdot$ Selective feeding $\cdot$ Behavıor

\section{INTRODUCTION}

Heterotrophic dinoflagellates are an important component of the marine microzooplankton, often approaching or exceeding the abundance of planktonic ciliates (Burkill et al. 1993, Verity et al. 1993), and they have been shown to be important grazers of diatoms (Hansen 1991. Tiselius \& Kuylenstierna 1996). Due to morphological constraints (2 flagella compared to the numerous cilia of ciliates), heterotrophic dinoflagellates do not feed by filtering small particles from the water as some ciliates do (Fenchel 1986); instead they capture individual phytoplankton cells, sometimes nearly as large or larger than themselves, and either

\footnotetext{
•E-mail: buskey@utmsi.zo.utexas.edu
}

engulf the entire cell or transfer body fluids of the captured cell into themselves by way of a pallium or a peduncle (Gaines \& Elbrächter 1987). Protoperidinium pellucidum, the subject of this study, is a pallium feeder, and captures and digests single phytoplankton cells (or chains of cells) externally (Jacobson \& Anderson 1986).

Since larger phytoplankton cells are often less abundant than smaller-sized cells, heterotrophic dinoflagellates may not rely on random encounter with suitable food cells and therefore need some sensory modality to help them locate individual food particles. After passing near a potential food item, the Protoperidinium spp. circles around the food several times, usually without contacting the cell (Jacobson \& Anderson 1986). This behavior suggests that chemoreception is used to recognize and locate a potential food item. Sev- 
eral previous studies have demonstrated the role of chemoreception in the feeding behavior of heterotrophic dinoflagellates (Hauser ef al. 1975, Spero 1985) and other protozoans (Levandowsky et al. 1984, Verity 1988). Pallium feeding dinoflagellates of the genus Protoperidinium have been previously shown to feed mainly on diatoms and dinoflagellates (Jacobson \& Anderson 1986, Hansen 1991. Buskey et al. 1994, Jeong \& Latz 1994). Although there have been some studies of selective feeding in marine protozoans (e.g. Stoecker et al. 1981, Verity 1991.), there has been little direct study of selective feeding in heterotrophic dinoflagellates, other than that based on prey size (Hansen 1992).

Although the trophic interaction between a pallium feeding heterotrophic dinoflagellate and a phytoplankton cell is most accurately described as a grazing interaction, since these grazers capture and consume their prey as individual targets (single cells or chains of cells), it can be constructive to examine this interaction in the context of a predator-prey interaction. Using the 'components of predation' framework of C. S. Holling (1959a, 1966), the behavioral components of this feeding interaction can be considered to include encounter, capture and ingestion. Since all aspects of this interaction can be easily observed and videotaped for more quantitative analysis with pallium feeders, it makes them excellent subjects for examining the behavioral components of selective feeding in marine protozoans. In the present study, the selective feeding of the paliium feeding heterotrophic dinoflagellate Protoperidinium pellucidum is investigated, and the behavioral components that affect selective feeding behavior are quantified.

\section{MATERIALS AND METHODS}

Plankton tows for culture of heterotrophic dinoflagellates were collected on the RV 'Gyre' during a LATEX (Louisiana-Texas Shelf Circulation Program) cruise in the Gulf of Mexico in May 1994 A $20 \mathrm{~cm}$ diameter, $20 \mu \mathrm{m}$ mesh plankton net was gently pulled through the surface waters while the ship was on station $\left(27^{\circ} 23^{\prime} \mathrm{N}, 95^{\circ} 37^{\prime} \mathrm{W}\right)$. Aliquots from these tows were then placed in $1 \mathrm{l}$ polycarbonate centrifuge bottles filled with filtered seawater and enriched with a mixture of cultured diatoms and autotrophic dinoflagellates (Ditylum brightwellii and Prorocentrum micans). These bottles were then placed in a deck incubator and kept at ambient surface temperature with a flow of surface seawater until the ship returned to shore. The heterotrophic dinoflagellate Protoperidinium pellucidum was isolated from an enrichment and brought into culture using these same phytoplankton species as food with the addition of Thalassiosira sp. 1 and Gonyaulax polyedra
Cultures of Protoperidinium pellucidum were maintained in $60 \mathrm{ml}$ tissue culture flasks or $250 \mathrm{ml}$ polycarbonate bottles in sterilized ciliate medium (Gifford 1985). Cultures were rotated within a translucent white PVC cylinder on a bottle roller at ca 2 rpm. Temperature was maintained at $20^{\circ} \mathrm{C}$ and cultures were held in subdued light (ca $1 \mu \mathrm{mol}$ photons $\mathrm{m}^{-2} \mathrm{~s}^{-1}$ ) on a 12 h light: 12 h dark cycle. Phytoplankton species used as food in these studies were cultured using $\mathrm{f} / 2$ medium (Guillard \& Ryther 1962), although silicate was omitted from the cultures of dinoflagellates. Phytoplankton were grown in polycarbonate $250 \mathrm{ml}$ Erlenmeyer flasks at $20^{\circ} \mathrm{C}$ on a $12 \mathrm{~h}$ light: $12 \mathrm{~h}$ dark cycle at ca $120 \mu \mathrm{mol}$ photons $\mathrm{m}^{-2} \mathrm{~s}^{-1}$. Only actively growing phytoplankton cultures (based on date of transfer) were used. Phytoplankton cells for elemental analysis were filtered onto precombusted GF/F filters, dried at $50^{\circ} \mathrm{C}$, and combusted in a Carlo-Erba EA 1108 elemental analyzer.

Specific growth rate was measured by adding ca 3 Protoperidinium pellucidum per $\mathrm{ml}$ to $150 \mathrm{ml}$ of ciliate culture medium in a $250 \mathrm{ml}$ polycarbonate bottle and adding Ditylum brightwelli, Thalassiosira sp. 1 , Gonyaulax polyedra or Prorocentrum micans at a range of food concentrations. A single bottle was inoculated at each food concentration, and the cultures were held at the same conditions as described above throughout the experiment. Triplicate $10 \mathrm{ml}$ samples were taken from each bottle at the same time daily over a $4 \mathrm{~d}$ period, preserved with 6 drops of $10 \%$ glutaraldehyde and stained with 3 drops of a $10 \mathrm{~g} \mathrm{l}^{-1}$ calcofluor solution and filtered onto $0.4 \mathrm{\mu m}$ pore size polycarbonate filters. Slides were stored frozen in the dark until enumeration (usually only a few days). Specific growth rates were calculated as the slope of the linear portion of $\ln (P$. pellucidum $\mathrm{ml}^{-1}$ ) regressed against time.

Grazing rate estimates and functional response curves were made for 2 food items: Ditylum brightwellii which supported higher maximum growth rates and Prorocentrum micans which supported lower maximum growth rates. A similar approach to that used with growth rate determination was employed, except that higher concentrations of Protoperidinium pellucidum were used at higher food concentrations or with food species for which $P$. pellucidum exhibited a lower feeding rate ( $P$. micans) and controls containing phytoplankton without grazers werc also prepared for each food concentration. Grazing experiments were run for $24 \mathrm{~h}$, and triplicate $10 \mathrm{ml}$ samples were taken at the beginning and end of each experiment. Grazer and food cell counts were determined microscopically using the blue fluorescence of the calcofluor-stained dinoflagellates and the red autoflourescence of their phytoplankton food. Ingestion and clearance rates were determined using the equations of Heinbokel (1978) 
Selective feeding experiments were conducted in polystyrene tissue culture plates with a total volume of ca $16 \mathrm{ml}$ per well. Approximately $10 \mathrm{ml}$ of ciliate culture media were added to each well and then 150 Protoperidinium pellucidum were transferred from cultures by pipet. The appropriate volume of phytoplankton culture was then added to result in the desired cell concentration. In the first experiment, 500 cells $\mathrm{ml}^{-1}$ of each of 4 food choices was used: Ditylum brightwellii, Thalassiosira sp. 1, Prorocentrum micans and Gonyaulax polyedra. Other experiments included 50 cells $\mathrm{ml}^{-1}$ of each of the same 4 phytoplankton cultures, 500 cells $\mathrm{ml}^{-1}$ of each of the 2 dinoflagellate species $(P$. micans and $G$. polyedra) and 100 cell $\mathrm{ml}^{-1}$ of each of $4^{\circ}$ diatom species (D. brightwellii, Thalassiosira spp. 1 and 2, and Biddulphia sp.). The feeding behavior of the $P$. pellucidum was then observed under a stereomicroscope. The first 50 grazers seen dragging food cells were then picked out and their food choices noted. This procedure was repeated 12 times for each experimental condition.

The swimming behavior of Protoperidinium pellucidum was recorded on a video cassette recorder for dinoflagellates in clear plastic tissue culture flasks $(60 \mathrm{ml}$ volume) or clear plastic spectrophotometry cuvettes (4 ml volume) using a Cohu model 3315 monochrome CCD video camera mounted on an Olympus SH stereo microscope at $40 \times$ magnification. Images were recorded using dark field illumination to enhance contrast. Swimming behavior of $P$. pellucidum was quantified from videotapes using an Expertvision Cell-Trak video-computer motion analysis system. Videotaped images of the dinoflagellates were digitized using the Motion Analysis VP-110 video-to-digital processor, and digitized outlines of the dinoflagellates were sent to a host computer at a rate of 15 frames per second. These digitized images were processed to calculate the swimming speeds $\left(\mathrm{mm} \mathrm{s}^{-1}\right)$ and the rate of change of direction (degrees $\mathrm{s}^{-1}$ ) of the dinoflagellates' paths of travel (Buskey 1984).

A set of preliminary experiments to examine the behavioral responses of Protoperidinium pellucidum to sensory stimuli associated with the presence of food were performed on cells removed from actively growing and feeding cultures, and quite variable results were achieved. Since a short period of starvation might make these cells more receptive to stimuli associated with food, an experiment was performed to examine the effects of starvation on their swimming behavior. Three $50 \mathrm{ml}$ tissue culture flasks were filled with filtered ciliate media and $P$. pellucidum were added at densities of approximately $10 \mathrm{ml}^{-1}$; the flasks were filmed 2 h after transfer, and after 24, 48, 72 and $96 \mathrm{~h}$ of starvation. Each flask was filmed for $10 \mathrm{~min}$ each day.
The chemosensory and mechanosensory responses of Protoperidinium pellucidum to its diatom prey Ditylum brightwellii was examined using an approach similar to that used by Buskey \& Stoecker (1989) to examine the behavioral responses to the tintinnid Favella sp. to its phytoplankton prey. Ten replicate groups of 150 $P$. pellucidum were placed in $4 \mathrm{ml}$ plastic spectrophotometry cuvettes with $3 \mathrm{ml}$ of ciliate media, and were starved for ca $20 \mathrm{~h}$. Each cuvette was then videotaped for $5 \mathrm{~min}$. Then $1 \mathrm{ml}$ of fresh filtrate from an actively growing $D$. brightwellii culture (filtered through a GF/F filter in a syringe holder) was added, and each cuvette was videotaped for an additional 5 min. Similar experiments were run to test the response of $P$. pellucidum to the presence of a $10^{-3} \mathrm{M}$ solution of the amino acid glycine. To test the response of $P$. pellucidum to mechanosensory signals associated with its diatom food, behavioral responses to inert polystyrene beads ( $44 \mu \mathrm{m}$ diameter) at a concentration of 500 beads $\mathrm{ml}^{-1}$ were recorded

In order to estimate the distance at which Protoperidinium pellucidum can recognize a potential food particle, we videotaped as many initial encounters between $P$. pellucidum and its food as possible. A few $P$. pellucidum were placed in a $4 \mathrm{ml}$ clear plastic spectrophotometry cuvette containing a suspension of a single species of phytoplankton, and the behavior of a single $P$. pellucidum was observed by moving the cuvette on the stage and adjusting the focus to keep the grazer in view. When a grazing interaction was observed, its location on the tape was noted for later analysis. When a $P$. pellucidum was swimming around a food cell before attaching to it, the maximum distance the $P$. pellucidum could move away from the cell without losing it was measured through frame-byframe image analysis of the feeding encounter, using Bioscan Optimas image analysis software. Only interactions where a minimum of 5 orbits around the food cell were observed were included in the analysis

The time required for Protoperidinium pellucidum to feed on a single cell of phytoplankton (Ditylum brightwellii, Thalassiosira sp. 1, Gonyaulax polyedra or Prorocentrum micans) was determined by direct observation under a stereomicroscope. A few $P$. pellucidum were placed in a petri dish with a suspension of a single species of phytoplankton. When $P$. pellucidum was observed to attach to a food cell, it was gently transferred to a cell well of a tissue culture plate and the time of capture was recorded. The feeding process was observed until $P$. pellucidum had dropped the remains of the food particle. A total of 50 feeding events were timed for each phytoplankton food species. A similar set of observations were made to determine the proportion of cells that were successfully captured. If a $P$. pellucidum attached to a phytoplankton cell, began 
towing it around and then lost it within a few seconds of capture, this event was scored as an 'escape'. If a $P$. pellucidum swam around a cell with a characteristic pre-feeding motion but lost contact with the cell before attachment, this interaction was scored as a 'lost contact'. A minimum of 100 feeding interactions were observed between $P$. pellucidum and each of the following foods: $D$. brightwellii, Thalassiosira sp. 1, G. polyedra and $P$. micans.

\section{RESULTS}

Cultures of Protoperidinium pellucidum actively grew when fed any of the diatom species offered in this study (Table 1). However, $P$. pellucidum would only feed and grow on 2 of the species of autotrophic dinoflagellates offered as food, Gonyaulax polyedra and Prorocentrum micans, and would not feed or grow on any of the other phytoplankton species used (Table 1). Of the foods found to support growth, 2 diatom species that supported good growth, Ditylum brightwellii and Thalassiosira sp. 1, and the 2 dinoflagellate species that supported growth, $G$. polyedra and $P$. micans, were selected for additional studies. These

Table 1 Foods fed to Protoperidinium pellucidum to test for consumption and growth. (+) P. pellucidum grew when fed this species, (-) no growth was observed. The volume of a $P$. pellucidum cell is approximately $24600 \mu \mathrm{m}^{3}$

\begin{tabular}{|c|c|c|}
\hline Food type & Growth & $\begin{array}{l}\text { Approx. volume } \\
\left(\mu m^{3}\right)\end{array}$ \\
\hline \multicolumn{3}{|l|}{ Diatoms } \\
\hline Biddulphia sp. & + & 6220 \\
\hline Corethron criophilum & + & 7890 \\
\hline Ditylum brightwellin & + & 9690 \\
\hline Nitzschia sp. & + & 2860 \\
\hline Skeletonema sp. ${ }^{d}$ & + & 200 \\
\hline Thalassiosira sp. 1 & + & 1850 \\
\hline Thalassiosira sp. 2 & + & 3613 \\
\hline \multicolumn{3}{|l|}{ Dinoflagellates } \\
\hline Gyrodinium dorsum & - & 30560 \\
\hline Gonyaulax polyedra & + & 17040 \\
\hline Gymnodinium simplex & - & 240 \\
\hline Gymnodınium sp. & - & 440 \\
\hline Heterocapsa niei & - & 1250 \\
\hline Helerocapsa pygmaea & - & 560 \\
\hline Prorocentrum micans & + & 18350 \\
\hline Prorocentrum minimum & - & 1530 \\
\hline \multicolumn{3}{|l|}{ Others } \\
\hline Cryptomonas sp. & - & 300 \\
\hline Dunaliella tertiolecta & - & 120 \\
\hline Emuliana huxleyi & - & 40 \\
\hline Isochrysis galbana & - & 70 \\
\hline Pyrenomonas salina & - & 210 \\
\hline \multicolumn{3}{|c|}{$\begin{array}{l}\text { "Forms chans up to } 145 \mu \mathrm{m} \text { in length in culture; this } \\
\text { volume is for a single cell }\end{array}$} \\
\hline
\end{tabular}

are the 4 food species that $P$. pellucidum had been grown on in culture since it was first isolated. CHN analysis of samples of the 4 phytoplankton foods used in the study revealed that $G$. polyedra had the largest biomass with $5024.6 \pm 363.7 \mathrm{pg} \mathrm{C} \mathrm{Cell}^{-1}$, followed by $P$. micans with $2308.5 \pm 337.8 \mathrm{pg} \mathrm{C} \mathrm{Cell}^{-1}, \mathrm{D}$. brightwelli. with $614.9 \pm 30.9 \mathrm{pg} \mathrm{C}$ cell ${ }^{-1}$ and Thalassiosira sp. 1 with $223.2 \pm 13.1 \mathrm{pg} \mathrm{C}$ cell $^{-1}$ The $\mathrm{C}: \mathrm{N}$ ratio was greatest for the Thalassiosira sp. 1 cultures at $6.83 \pm 0.09$, followed by $G$. polyedra $(6.68 \pm 0.05)$, P. micans $(6.50 \pm$ $0.09)$ and $D$. brightwellii $(6.01 \pm 0.16)$. The cell volume of $P$. pellucidum was estimated to be $24600 \mu^{3}$. This would yield an estimated biomass of $3444 \mathrm{pg} \mathrm{C}$ cell $^{-1}$ using a carbon:cell volume ratio of $0.14 \mathrm{pg}{\mathrm{C} \mu \mathrm{m}^{-3}}^{-3}$ (measured for Oblea rotunda by Lessard, cited in Strom \& Buskey 1993)

Protoperidinium pellucidum exhibited higher maxi mum specific growth rates on diets of the diatoms Ditylum brightwellii or Thalassiosira sp. 1 than on either of the dinoflagellate diets (Fig. 1). For both diatoms diets, maximum specific growth rates of $\mathrm{ca} 0.7 \mathrm{~d}^{-1}$ were

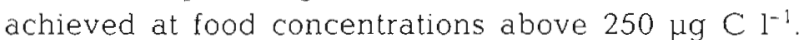
When offered diets of either Gonyaulax polyedra or Prorocentrum micans, maximum specific growth rates of only ca $0.4 \mathrm{~d}^{-1}$ were achieved at much higher food concentrations (above $750 \mu \mathrm{g} \mathrm{C} \mathrm{l}^{-1}$ ). P. pellucidum showed higher maximum ingestion rates on $D$. brightwellii than on $P$. micans, both in terms of cells consumed ind.$^{-1} \mathrm{~h}^{-1}$ and in terms of $\mathrm{ng} \mathrm{C}$ ingested ind.-1 $\mathrm{h}^{-1}$ (Fig. 2). P. pellucidum had a maximum ingestion rate for $D$. brightwellii of $0.48 \mathrm{ng} \mathrm{C}$ ind. ${ }^{-1} \mathrm{~h}^{-1} 10.78$ cells $\mathrm{h}^{-1}$ ) at food concentrations above $350 \mu \mathrm{g} \mathrm{Cl}^{-1}$, but for $P$. micans the maximum ingestion rate was only $0.32 \mathrm{ng} C$ ind. ${ }^{-1} h^{-1}\left(0.14\right.$ cells $\left.h^{-1}\right)$ at food concentrations above $850 \mu \mathrm{g} \mathrm{C} \mathrm{^{-1 }}$.

When Protoperidinium pellucidum was allowed to choose between Ditylum brightwellii, Thalassiosira sp. 1, Gonyaulax polyedra or Prorocentrum micans at concentrations of 500 cells $\mathrm{ml}^{-1}$ of each food (2000 cells $\mathrm{ml}^{-1}$ total phytoplankton concentration), $P$. pellucidum showed a very strong preference for $D$. brightwellii, which was chosen $88 \%$ of the time (Fig. 3). Thalassiosira sp. 1 was chosen $8 \%$ of the time while G. polyedra was only chosen $1.3 \%$ of the time and P. micans only $2.7 \%$ of the time. When concentration of the 4 food species were lowered to 50 cells $\mathrm{ml}^{-1}$ of each food (200 cells $\mathrm{ml}^{-1}$ total), strong preference was still shown for diatoms, but $D$. brightwellii was chosen only $66.8 \%$ of the time. The number of times Thalassiosira sp. 1 was chosen increased to $27.8 \%$, but the number of times dinoflagellate prey was chosen remained low at $2.7 \%$ for $G$. polyedra and $2.7 \%$ for $P$. micans. When concentrations of the 4 food species were lowered to 10 cells $\mathrm{ml}^{-1}$ of each food, too few feeding interactions were observed to complete the experiment. When $P$. 
Fig. 1 Protoperidinium pellucidum. Specific growth rate as a function of mean food concentration over a 4 d experiment. Food species used were Ditylum brightwellii, Thalassiosira sp. 1, Gonyaulax polyedra and Prorocentrum micans
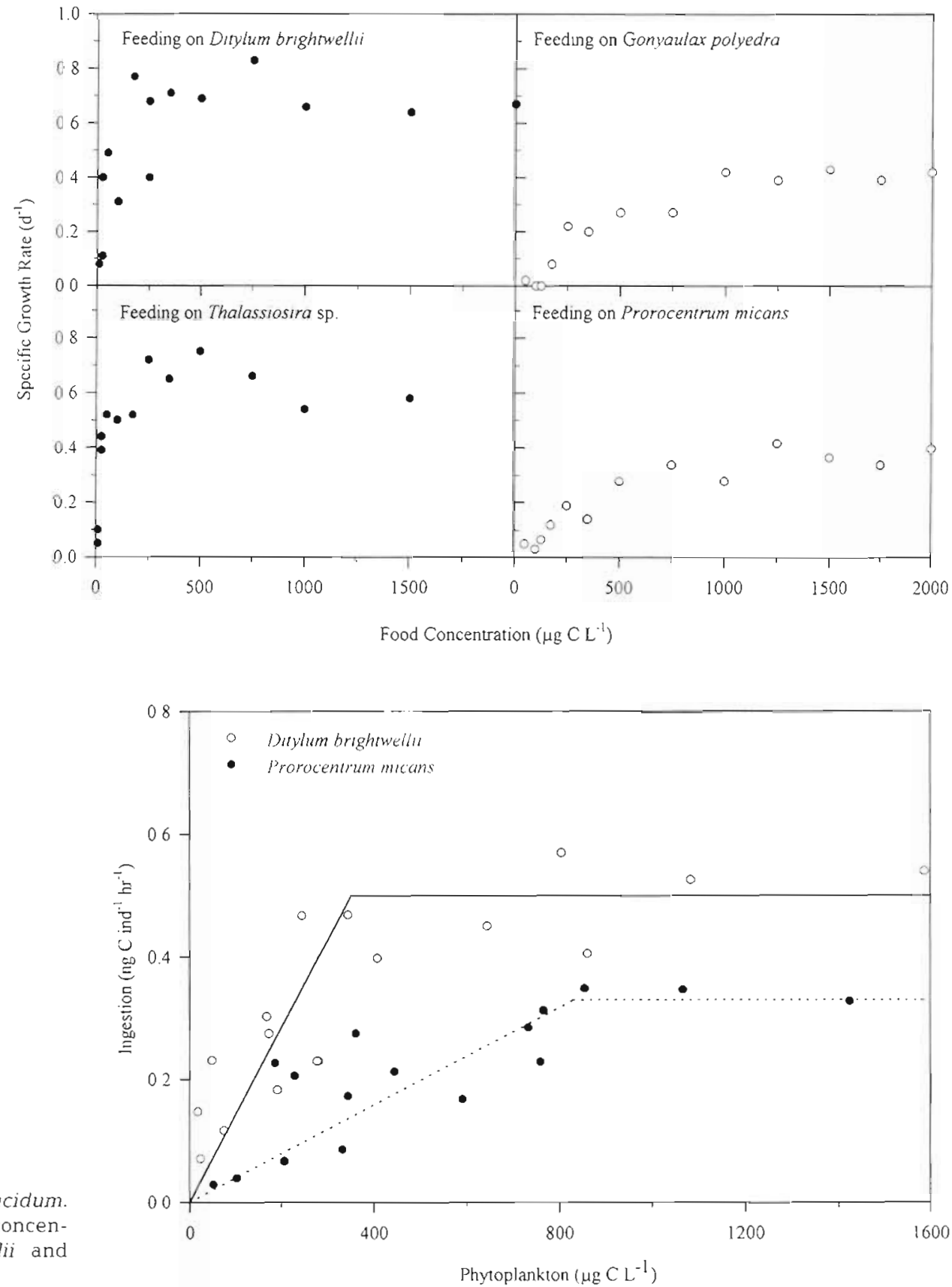

Fig. 2. Protoperidinsum pellucidum. Ingestion rate over a range of concentrations of Ditylum brightwellii and Prorocentrum micans
$39 \pm 18.5 \%$ of the time; Thalassiosira sp. 1 was chosen $4 \pm 2 \%$ and Biddulphia sp. $8 \pm 1.9 \%$ of the time.

Starvation affected the behavior of Protoperidinium. pellucidum by causing a decrease in swimming speed over the first $48 \mathrm{~h}$ of starvation (Fig. 4). After $48 \mathrm{~h}$ of starvation, there appeared to be little additional change in swimming speed until the experiment was ended at 96 h. Measures of rate of change of direction showed more variability, although mean rate of change of direction did decrease over the first $48 \mathrm{~h}$.

\begin{abstract}
When exposed to a filtrate from a fresh Ditylum bright-
\end{abstract} siosira sp. 2 was chosen $49 \pm 9.2 \%$ and $D$. brightwellij pellucidum were allowed to choose only between the 2 dinoflagellate species at 500 cells $\mathrm{ml}^{-1}$ of each food there was a slight preference for $P$. micans $158.6 \pm$ $18.4 \%)$ over $G$. polyedra $(41.4 \pm 18.4 \%)$. A final selec ve feeding experiment was performed using 4 differsecies of diatom (D. brightwellii. Thalassiosil sp. 1, Biddulphia sp., and Thalassiosira sp. 2). In this experiment, the 2 largest diatom species, $D$. brightwellii and Thalassiosira sp. 2 were chosen approxi- 


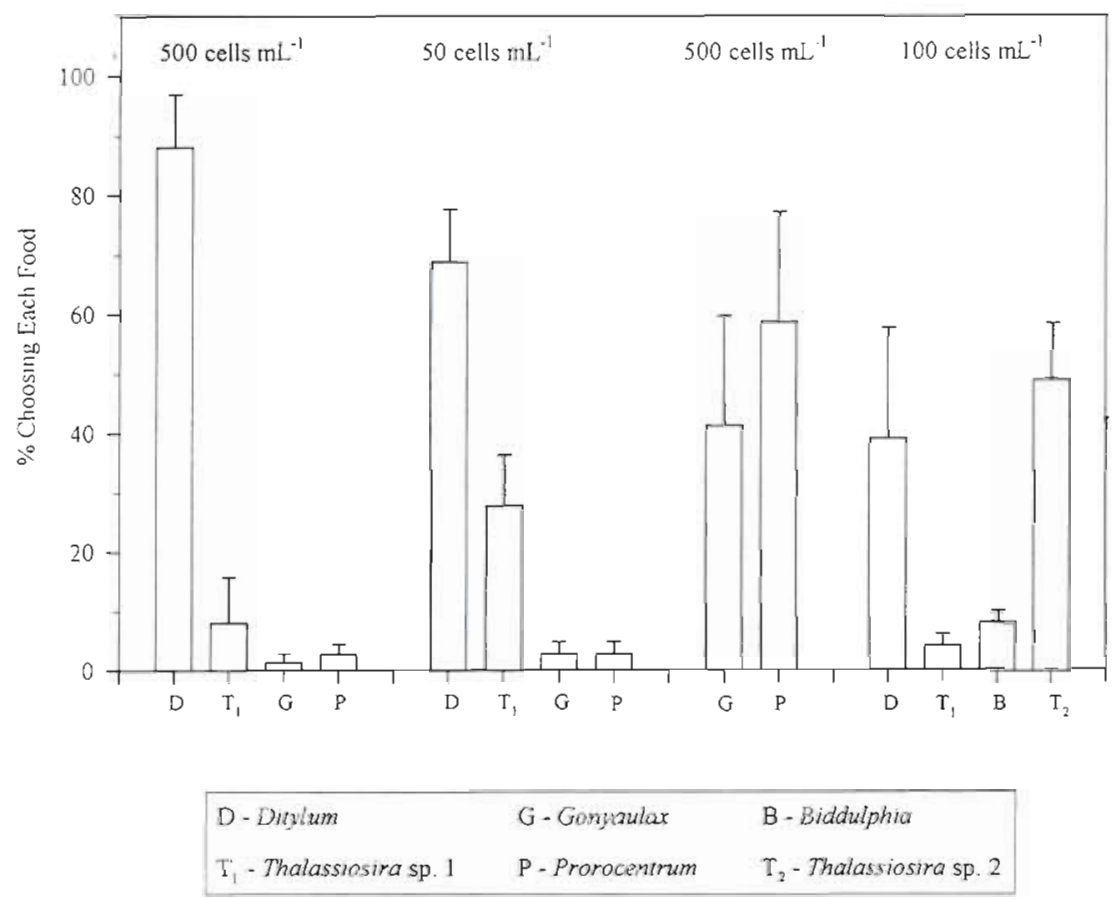

Fig. 3. Protoperidinium pellucidum. Feeding selectivity studies. Percent of the time that each of 4 phytoplankton foods (Ditylum brightwellii, Thalassiosira sp. 1, Gonyaulax polyedra or Prorocentrum micans) were chosen at food concentrations of 500 cells $\mathrm{ml}^{-1}$ or 50 cells $\mathrm{ml}^{-1}$ of each food, that each of 2 dinoflagellate species were chosen at 500 cells $\mathrm{ml}^{-1}$, or that each of 4 diatom species (Ditylum brightwellii, Thalassiosira sp. 1, Biddulphia sp. or Thalassiosira $\mathrm{sp}$. 2) were chosen at 100 cells $\mathrm{ml}^{-1}$

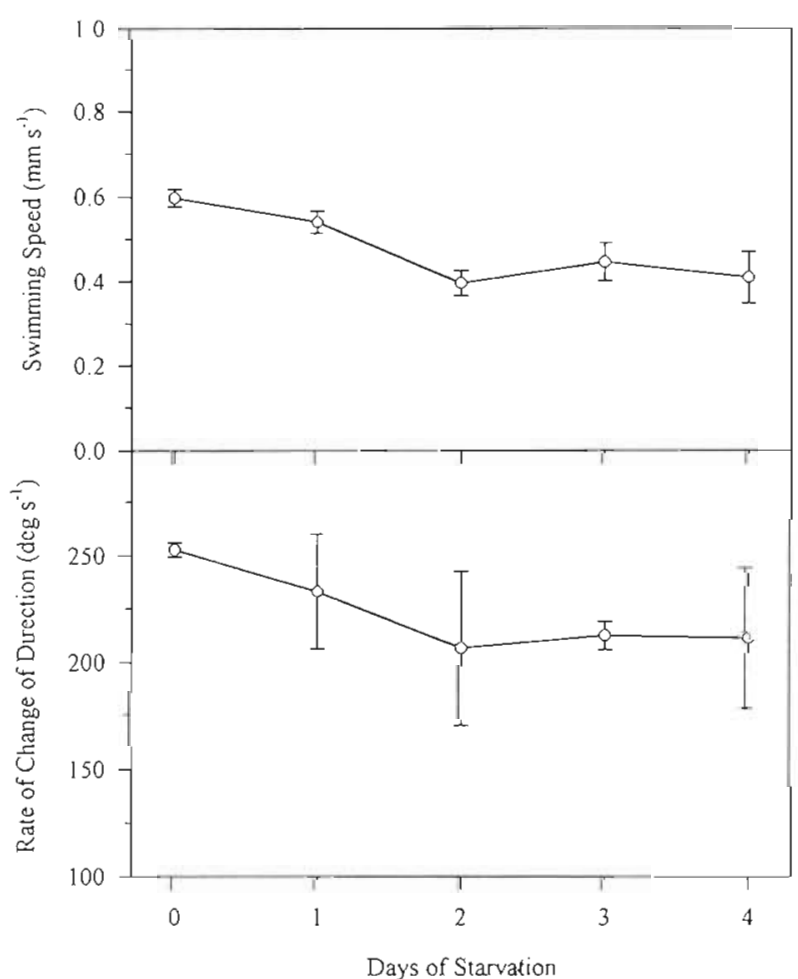

Fig. 4. Protoperidinium pellucidum Effects of starvation on the swimming behavior. Changes in. swimming speed and rate of change of direction over a $96 \mathrm{~h}$ period of starvation wellii culture, $P$. pellucidum that had been starved $24 \mathrm{~h}$ showed an increase in swimming speed (Fig. 5) and a decrease in turning rate. Before addition of the filtrate, the starved $P$. pellucidum had an average swimming speed of $0.48 \pm 0.04 \mathrm{~mm} \mathrm{~s}^{-1}$ (grand mean of 10 replicates $\pm 1 \mathrm{SD}$ ) and an average turning rate of $249^{\circ} \mathrm{s}^{-1}$. After addition of filtrate from the phytoplankton culture, there was a significant increase in swimming speed to $0.57 \pm 0.06 \mathrm{~mm} \mathrm{~s}^{-1}$ (Student's $t$-test with paired design, $\alpha=0.05$ ) and a significant decrease in turning rate to $203^{\circ} \mathrm{s}^{-1}$ (Student's $t$-test with paired design, $\alpha=0.05)$. $P$. pellucidum showed a similar behavioral response when exposed to $10^{-3} \mathrm{M}$ seawater solution of the amino acid glycine (Fig. 6). These behavioral responses to chemosensory stimuli observed in the first 5 min of exposure were transient; swimming speeds and turning rates returned to previous values within an hour, probably due to adaptation of sensory systems. P. pellucidum showed no significant changes in swimming speed or turning rate when inert polystyrene beads ( $44 \mathrm{\mu m}$ diameter) were added at a concentration of 500 beads $\mathrm{ml}^{-1}$.

Image analysis of the stereotypical pre-feeding behavior of circling around a prey cell before attaching to it, revealed only small differences in the maximum distance between Protoperidinium pellucidum and its prey for all 4 phytoplankton species tested. For fifty measures of the maximum distance measured, the mean distance ( $\pm 1 \mathrm{SD}$ ) was $123 \pm 35 \mu \mathrm{m}$ for Ditylum brightwellii, $108 \pm 28 \mu \mathrm{m}$ for Thalassiosira sp. 1 . 


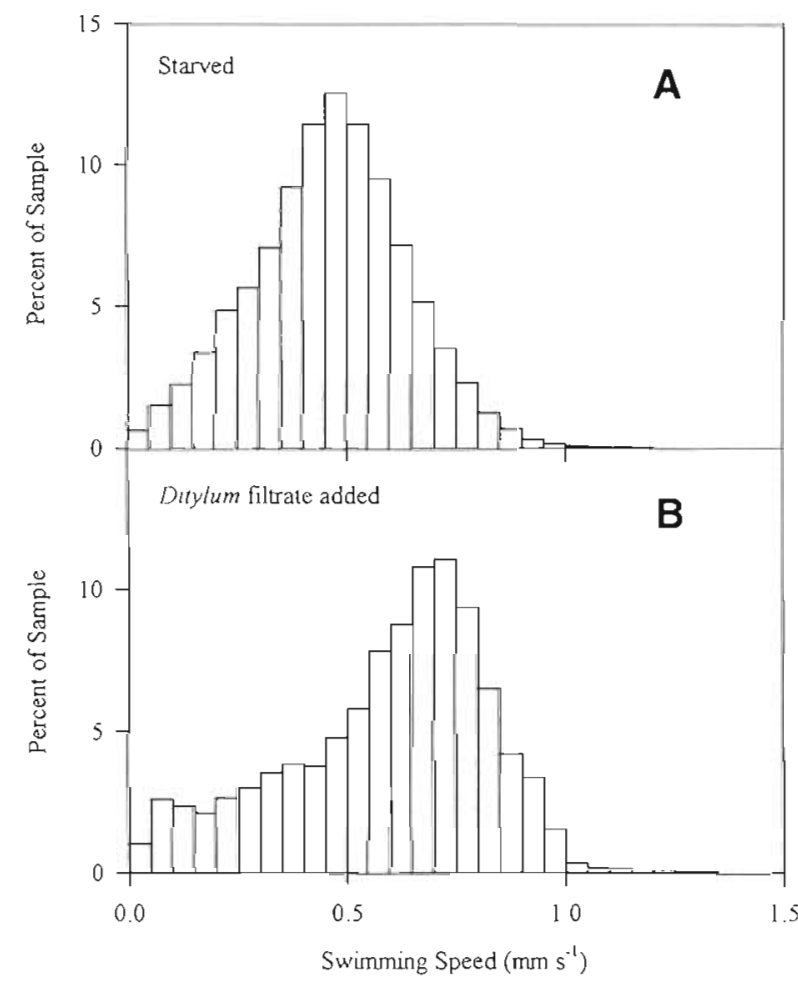

Fig. 5. Protoperidinium pellicidum. Distribution of swimming speeds (A) after ca $20 \mathrm{~h}$ of starvation and (B) after having been exposed to a fresh filtrate from a culture of actively growing Ditylum brightwelli

$97 \pm 23 \mu \mathrm{m}$ for Gonyaulax polyedra and $94 \pm 22 \mu \mathrm{m}$ for Prorocentrum micans.

The capture phase of the feeding interaction between Protoperidinium pellucidum and its phytoplankton food was quantified for the frequency of successful captures, lost contacts and escapes after attachment for each of 4 different food types. This type of behavioral analysis is made possible by the stereotyped circling behavior which precedes the attachment phase of feeding, and the ability to directly observe the initial attachment of a $P$. pellucidum to its food cell. Feeding interactions between $P$. pellucidum and diatoms were nearly always successful. In over 100 observed feeding interactions, an interaction where a Ditylum brightwellii cell was not successfully captured was never observed. In only 2 instances were cells lost after attachment during over 100 feeding interactions observed between $P$. pellucidum and Thalassiosira sp. 1. In contrast, over $20 \%$ of Gonyaulax polyhedra and over $40 \%$ of Prorocentrum micans were able to break the tow thread and escape after initial capture by $P$. pellucidum (Table 2).

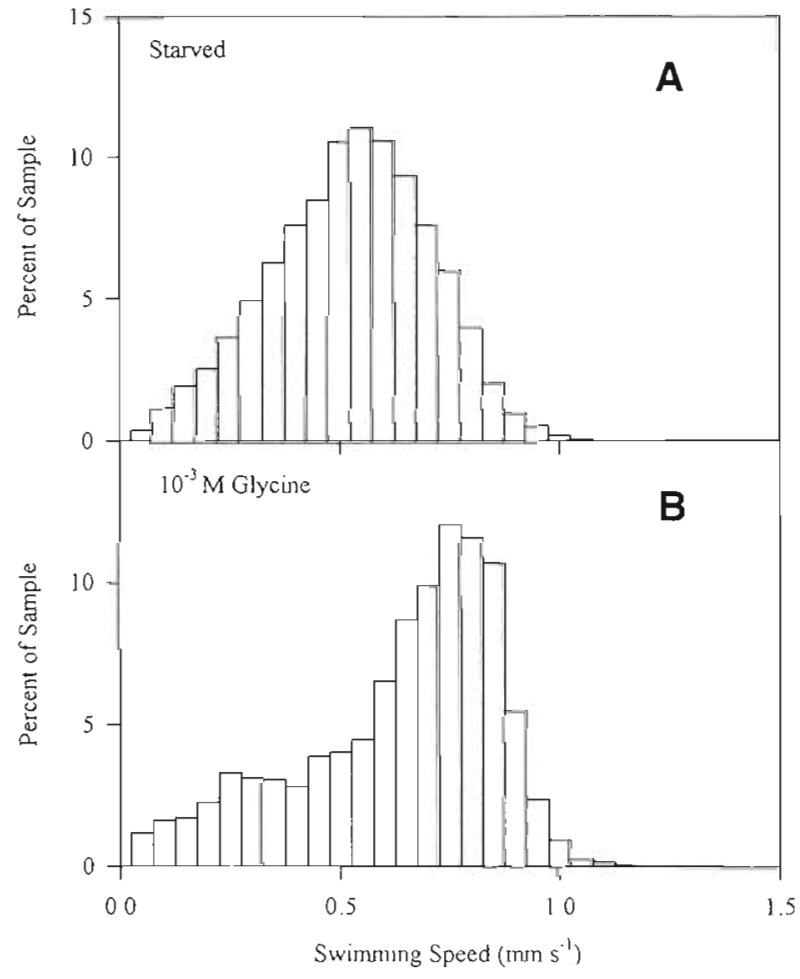

Fig. 6. Protoperidinium pellucidum. Distribution of swimming speeds (A) after ca $20 \mathrm{~h}$ of starvation and (B) after having been exposed to seawater containing $10^{-3} \mathrm{M}$ solution of the amino acid glycine

Clearly, $P$. pellucidum has a higher success rate capturing non-motile cells (diatoms) than motile cells (autotrophic dinoflagellates). It is unclear why there was a higher escape rate for the slower swimming species ( $P$. micans, $0.1 \mathrm{~mm} \mathrm{~s}^{-1}$ ) compared to the faster swimming species (G. polyedra, $0.4 \mathrm{~mm} \mathrm{~s}^{-1}$ ). P. pellucidum also tended to lose contact with motile dinoflagellate prey in over $10 \%$ of the interactions observed, but this was not observed in feeding interactions with diatoms (Table 2).

Table 2. Observed feeding interactions between Protoperidinium pellucidum and 4 potential food types: Ditylum brightwellii, Thalassiosira sp. 1 Gonyaulax polyedra and Prorocentrum micans. If $P$. pellicudum formed a pallium around its food cell, it was scored as a successful capture. If the cell was lost after the tow thread was attached, it was scored as an escape. If $P$. pellucidum circled the cell in a stereotypical feeding behavior, but failed to attach a tow thread, it was scored as a lost contact. $\mathrm{n}=$ no. of observations

\begin{tabular}{|lccccc|}
\hline Prey & $\begin{array}{c}\text { Prey speed } \\
\left(\mathrm{mm} \mathrm{s}^{-1}\right)\end{array}$ & $\begin{array}{c}\text { Successful } \\
\text { capture }\end{array}$ & Escape & $\begin{array}{c}\text { Lost } \\
\text { contact }\end{array}$ & $\mathrm{n}$ \\
\hline Ditylum brightwellii & 0 & $100 \%$ & 0 & 0 & 115 \\
Thalassiosira sp. 1 & 0 & $98.3 \%$ & $1.7 \%$ & 0 & 116 \\
Gonyaulax polyedra & 0.4 & $61.9 \%$ & $21.2 \%$ & $16.9 \%$ & 118 \\
Prorocentrum micans & 0.1 & $46 \%$ & $43 \%$ & $11 \%$ & 100 \\
\hline
\end{tabular}


The time required for Protoperidinium pellucidum to ingest a phytoplankton cell varied with the food species, although it was similar for the dinoflagellate species (Table 3). Feeding time increased proportionally with the biomass of the phytoplankton cell consumed for Thalassiosira sp. 1, Ditylum brightwellii and Prorocentrum micans, but did not significantly increase for the larger Gonyaulax polyedra cells (Fig. 7). It is possible that there may be a maximum average feeding time for $P$. pellucidum of about $70 \mathrm{~min}$; this may represent the time required for $P$. pellucidum to ingest the maximum amount of carbon it can assimilate, or it might simply represent the maximum average time for a single pallium feeding event. There is quite a bit of variability in our measured digestion times for different foods; this may be due in part to release of the pallium before the food cell is completely digested. It is suspected that this may occur for a number of reasons, and. that a more accurate estimate of time required to ingest the entire cell may be given by the 'most probable value', which is defined as the mean of the upper half of measurements (Fig. 7, Table 3).

\section{DISCUSSION}

The survey of potential foods indicates that Protoperidinium pellucidum will grow on a wide range of diatom species (Table 1). This is in agreement with previous studies indicating that some species of Protoperidinium appear to prefer diatoms as food (Jacob- son \& Anderson 1986, Buskey et al. 1994). P. pellucidum. would grow on only 2 of the 8 monospecific dinoflagellate diets offered, suggesting that autotrophic dinoflagellates as a group were somehow less suitable as food items. However, it is interesting to note that all foods that supported growth of $P$. pellucidum fell between the approximate volumes of 1850 and $18350 \mu \mathrm{m}^{3}$, while all the phytoplankton species that did not support growth fell outside this size range (total volume of chains of the smaller Skeletonema $\mathrm{sp}$. cells also fall within this range). This indicates that size plays an important role in suitability of food for P. pellucidum.

A comparison of growth rates of $P$. pellucidum on 2 species of diatom (Ditylum brightwellii, Thalassiosira sp. 1) and 2 species of dinoflagellate (Gonyaulax polyedra, Prorocentrum micans) show that $P$. pellucidum has a higher specific growth rate when fed diatoms $\left(0.7 \mathrm{~d}^{-1}\right)$ compared to a dinoflagellate diet $\left(0.4 \mathrm{~d}^{-1}\right)$ (Fig. 1). Based on the limited evidence available, there may be a general trend of higher growth rates for Protoperidinium species fed diatoms compared to those

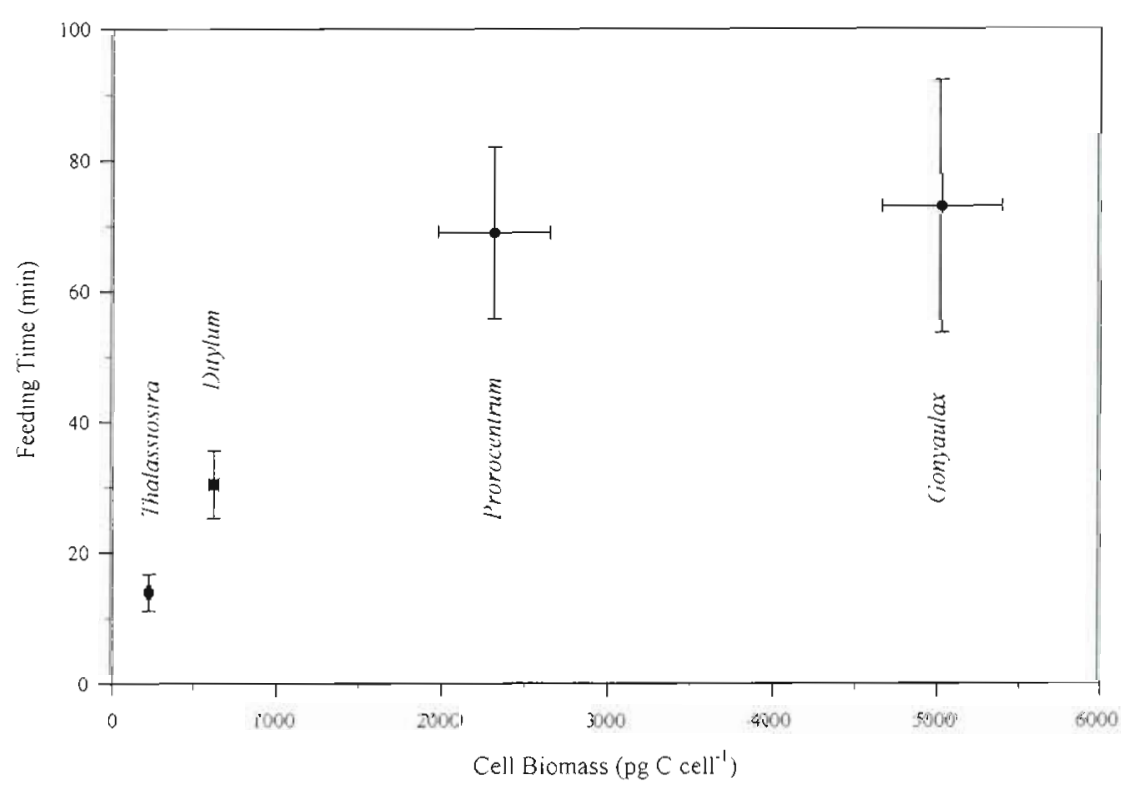

Fig. 7 Protoperidinium pellucidum. Time required to feed on a single cell of Ditylum brightwelli, Thalassiosira sp., Gonyaulax polyedra or Prorocentrum micans as a function of the biomass of the food cell. Most probable value $(M P V) \pm 1 S D, n=25$ 
fed autotrophic dinoflagellates. Jacobson \& Anderson (1993) and Buskey et al. (1994) found maximum specific growth rates of $1.23 \mathrm{~d}^{-1}$ and $0.72 \mathrm{~d}^{-1}$, respectively, for Protoperidinium species fed diatoms, whereas Jeong \& Latz (1994) found maximum specific growth rates of 0.48 and $0.31 \mathrm{~d}^{-1}$ for 2 species of Protoperidinium fed dinoflagellates. However, it should be noted that the Protoperidinium species with the higher growth rates were also smaller in size, and an alternative explanation might be that smaller species have greater maximum growth rates than larger species. $P$. pellucidum also exhibited higher maximum ingestion rates when fed the diatom Ditylum brightwellii compared to the autotrophic dinoflagellate Prorocentrum micans (Fig 2). A previous study suggested that Protoperidinium species ( $P$. cf. divergens and $P$. crassipes) might play important roles as grazers of dinoflagellates in red tide blooms when high concentrations of dinoflagellates existed (Jeong \& Latz 1994). Other species of Protoperidinium appear to feed preferentially on diatoms and, along with other species of heterotrophic dinoflagellates, may play an important role in grazing diatom blooms (Hansen 1991, Tiselius \& Kuylenstierna 1996). Selective feeding by rapidly growing heterotrophic dinoflagellate species may play a role in determining phytoplankton community structure.

In feeding selectivity studies, Protoperidinium pellucidum showed strong preference for diatoms over dinoflagellates (Fig. 3). Pallium feeding heterotrophic dinoflagellates are particularly amenable to studies of feeding selectivity, since each organism selects a single food cell and remains attached to it for periods of up to an hour, allowing for easy visual determination of the food species chosen. It would seem that this feeding selectivity is not a result simply of the size or shape of the food cell, since there usually appears to be no contact between the $P$. pellucidum and the food cell until the tow thread is attached and the selection has been made. Although the role of prey size and shape in food selection has not been specifically investigated for pallium feeding heterotrophic dinoflagellates, these protists show remarkable range in the sizes of individual phytoplankton cells they can capture and consume, from $1 \%$ to over $500 \%$ of their own cell volume (Strom \& Buskey 1993, Buskey et al. 1994). When food selectivity was tested amoung 4 species of diatoms, selection was not directly related to size. Thalassiosira sp. 2 (cell volume of $3613 \mu^{3}$ ) was chosen $48 \%$ of the time, Ditylum brightwellii (cell volume $9690 \mu^{3}$ ) was chosen $39 \%$ of the time, Biddulphia sp. (cell volume $6220 \mu^{3}$ ) was chosen $8 \%$ of the time, and Thalassiosira sp. 1 (cell volume $1850 \mu^{3}$ ) was chosen $4 \%$ of the time. However, there is indirect evidence that chemosensory perception may play a role in feeding selectivity. $P$. pellucidum shows a clear behavioral response to chemosensory signals associated with its phytoplankton prey (Fig. 5) and to a solution of a single amino acid (Fig 6), indicating that it is capable of remote perception of chemosensory signals associated with the phytoplankton it feeds on. Several previous studies have demonstrated chemosensory capabilities in heterotrophic dinoflagellates and indicated a potential role of free amino acids in chemosensory responses of heterotrophic dinoflagellates and other protozoa (Hauser et al. 1975, Fitt 1985, Spero 1985). It seems likely that initial food choice by $P$. pellucidum is made by means of remotely detected chemosensory signals that stimulate the stereotypical pre-feeding behavior. More study is needed to determine the extent to which $P$. pellucidum can distinguish between chemosensory signals associated with specific phytoplankton species.

Optimal foraging theory predicts that predators should selectively feed on the largest prey they can handle and that feeding selectivity should be greater when the food is more abundant (Pyke et al. 1977). If size were the only factor determining which food species would be most 'profitable' to consume, one would predict that Protoperidinium pellucidum should select the 2 dinoflagellates over the 2 diatom species offered as food. Not only were the 2 dinoflagellates larger than the 2 diatoms, but when handling times were factored in, carbon ingested per minute was about twice as high for dinoflagellates compared to diatoms. There must be other factors affecting the nutritional quality and attractiveness of diatoms as food. Studies of the chemical composition of phytoplankton (e.g. Parsons et al. 1961, Moal et al. 1987) do not reveal general patterns that help explain the higher maximum growth rates of $P$. pellucidum when fed diatoms. However, it is interesting to note that $P$. pellucidum demonstrated a stronger preference for Ditylum brightwellii at high food concentrations (500 cells $\mathrm{ml}^{-1}$ of each of 4 foods) than at lower food concentrations (50 cells $\mathrm{ml}^{-1}$ of each of 4 foods) (Fig 3), supporting the idea of increased selectivity for preferred foods at high concentrations predicted by optimal foraging theory.

In order to understand the factors contributing to this apparent selection for diatom prey over dinoflagellate prey, it is useful to examine the feeding behavior of Protoperidinium pellucidum using the 'components of predation' framework of Holling (1959a, 1966). Thus we can consider separately the factors affecting encounter, capture and ingestion of different prey types by $P$. pellucidum. The encounter rates between $P$. pellucidum and its food can be predicted based on the encounter model of Gerritsen \& Strickler (1977) The behavioral parameters needed for this model include the swimming speeds of the 'predator' ( $P$. pellucidum) and its 'prey' (diatoms or autotrophic dino- 
flagellates), prey density and the distance at which prey can be detected by the sensory systems of the predator (the 'encounter radius') All of these parameters can be measured for interactions between $P$. pellucidum and its phytoplankton food.

The most difficult parameter to estimate for encounter models is the encounter radius, the distance at which a predator detects its prey. Error in estimating this parameter will have a much larger effect on estimates of encounter rate than errors in measuring swimming speeds or prey density, since the term is squared in the encounter model equation of Gerritsen \& Strickler (1977). Previous studies using encounter models to estimate encounter frequencies have sometimes simply guessed at an appropriate value (e.g Buskey \& Swift 1990). The size of the 'encounter radius' for Protoperidinium pellucidum feeding on 4 different species of phytoplankton was estimated by measuring the maximum distances that $P$. pellucidum could move away from its food without losing contact with it during $P$. pellucidum's stereotypical pre-feeding behavior, in which it circles the cell before attaching to it. This may underestimate the maximum distance at which a food cell can be detected, but it should be proportional to the size of the 'active space' (Bossert \& Wilson 1963, Andrews 1983) around the food cell containing chemosensory signals recognizable to P. pellucidum. It seems reasonable that this encounter distance should be greater for larger-sized cells which

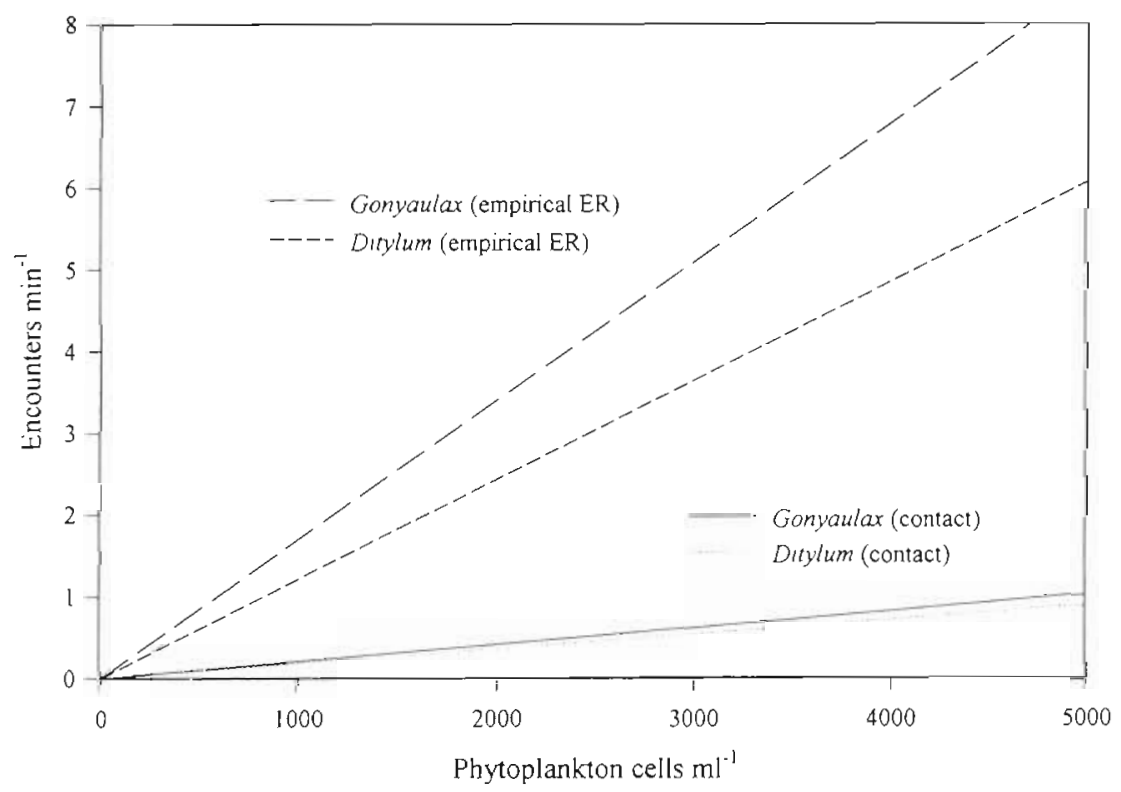

Fig. 8. Predicted encounter rates between Protoperidinium pellucidum and 2 phytoplankton species, Gonyaulax polyedra and Ditylum brightwellii. Encounter rates are predicted from the encounter model of Gerritsen \& Strickler (1977) based on the assumption that cells must physically collide to encounter one another (contact) or that $P$. pellucidum can remotely detect phytoplankton prey at a distance equivalent to an empirically determined encounter radius (empirical. ER) might release more dissolved organic substances that could be used as chemosensory cues. It also seems intuitive that motile dinoflagellates would have differently shaped 'active spaces' surrounding their cells; they would tend to leave a trail of scent behind in addition to a small sphere of dissolved chemicals in the waters trapped in a boundary layer around them. This should make dinoflagellates more difficult to detect at low concentrations compared to non-motile diatoms, which should produce larger and more symmetrically shaped 'active spaces' around each cell. Our results show that the active spaces are slightly larger for larger diatoms compared to smaller diatoms (Ditylum. brightwellii vs Thalassiosira sp. 1), and are larger for diatoms compared to dinoflagellates per unit cell volume. However, the empirically estimated encounter radii were highly variable and not significantly different for the species we tested. The method used to estimate this distance (the maximum distance measured between cells during stereotypical pre-feeding behavior) may not accurately reflect the distance at which initial perception of the cell was made.

Estimates of swimming speeds of Protoperidinium pellucidum and its food cells are also needed to predict encounter frequencies. The average swimming speed for well-fed $P$. pellucidum is ca $0.6 \mathrm{~mm} \mathrm{~s}^{-1}$. This is similar to but slightly higher than speeds measured for 2 other species of Protoperidinium ( $P$. depressum, $P$. pacificum) using the same method (Buskey et al. 1993).

Swimming speeds of the 2 motile autotrophic dinoflagellates used as food in this study were $0.4 \mathrm{~mm}$ $\mathrm{s}^{-1}$ for Gonyaulax polyedra and $0.1 \mathrm{~mm} \mathrm{~s}^{-1}$ for Prorocentrum micans. Diatoms are non-motile, and were considered to have a 'swimming speed' of zero, although they may sink slowly through the water column.

Using these estimates of encounter radius, and our measures of swimming speed for Protoperidinium pellucidum and its motile autotrophic dinoflagellate prey (e.g. Gonyaulax polyedra) the encounter model of Gerritsen \& Strickler (1977) can be used to predict encounter rates between $P$. pellucidum and its prey at different prey densities (Fig 8). Comparing encounter rates with the motile $G$. polyedra $\left(0.4 \mathrm{~mm} \mathrm{~s}^{-1}\right)$ and nonmotile diatom Ditylum brightwellii $\left(0 \mathrm{~mm} \mathrm{~s}^{-1}\right)$, if we assume that $P$. pellucidum must physically run into 
and contact its food to detect it (i.e. encounter radius is equivalent to the distance between the centers of the 2 cells when they contact (ca $40 \mu \mathrm{m}$ ), it is clear that encounter rates are very low, and only slightly higher for the motile prey compared to the non-motile prey (Fig. 8). In both cases, encounter rates only approach $1 \mathrm{~min}^{-1}$ at cell densities of 5000 cells $\mathrm{ml}^{-1}$. However, if we use our empirically determined estimates of encounter radius and recalculate the changes in encounter rate with food density, it is clear that these small increases in encounter radius have an enormous effect on encounter rate. Now encounter rates of 1 encounter $\mathrm{min}^{-1}$ occur at cell densities $<1000$ cells $\mathrm{ml}^{-1}$ It is also apparent that the effects of a slightly larger encounter radius for detecting $D$. brightwellii increase encounter rate more than the motility of $G$. polyedra.

The second 'component of predation' to be considered in the interaction between Protoperidinium pellucidum and its phytoplankton prey is capture probability. Very little is known about the factors affecting food capture success in pallium feeding heterotrophic dinoflagellates. In other planktonic predator-prey interactions, prey escape may play an important role in predator selectivity (Drenner et al. 1978, Landry 1978 , Greene \& Landry 1985). The selection of P. pellucidum for diatoms over dinoflagellates may relate at least in part to the motility of the autotrophic dinoflagellates, compared to the lack of motility in diatoms. P. pellucidum was never observed to 'lose contact' with a nonmotile diatom once it began its stereotypical circling behavior, but it was observed to lose contact with Gonyaulax polyedra in $17 \%$ of interactions and with Prorocentrum micans in $11 \%$ of interactions. Even though the motility was not in direct response to the approach of the heterotrophic dinoflagellate, the motility of the autotrophic dinoflagellates appears to have aided in their escape, perhaps due to the lower ability of $P$. pellucidum to locate and remain near a moving cell. Similarly, once $P$. pellucidum had attached a tow thread to a diatom, failure to engulf the cell in its pallium was never observed when Ditylum brightwellii was the food, and was observed in only 2 instances with Thalassiosira sp. 1 (Table 2). Failure to capture Thalassiosira sp. 1 cells in these rare instances may have been related to the presence of extensive marginal threads of Thalassiosira that have been demonstrated to interfere with the feeding of tintinnid ciliates (Verity \& Villareal 1986); these threads may have interfered with the ability of $P$. pellucidum to securely attach the tow thread to the frustule. The loss of motile dinoflagellate cells after attachment of the tow thread seemed to be the result of detachment or breakage of the thread when the 2 cells swam in different directions. It did not appear that the feeding attempt by $P$. pellucidum elicited a specific escape response in the autotrophic dinoflagellates, but the normal swimming behavior of the dinoflagellates did appear to aid in their escape.

The final 'component of predation' to be considered for the feeding behavior of Protoperidinium pellucidum is ingestion. The fact that $P$. pellucidum and other pallium feeding heterotrophic dinoflagellates digest their prey externally allows us to accurately measure the time required for digestion of different food types. The $P$. pellucidum cell engulfs its food in a pallium and remains attached to it until apparently only non-digestible materials remain (e.g. diatom frustule, dinoflagellate thecal plates). There appears to be a relationship between MPV digestion time and the carbon content of the cells consumed up to a maximum average ingestion time of about 70 min (Fig. 7). However, when the values for carbon content per cell for each prey type are divided by the time required to consume them, the average carbon ingested per

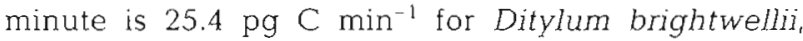
$21.7 \mathrm{pg} \mathrm{C} \mathrm{min}^{-1}$ for Thalassiosira sp. $1,93.5 \mathrm{pg} \mathrm{C} \mathrm{min}^{-1}$

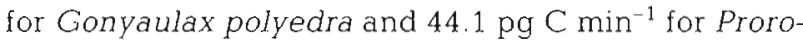
centrum micans. For the dinoflagellates, however, some of the carbon measured for each cell is in the form in indigestible material in the theca which would be left behind in the pallium, and this may cause an overestimation of carbon consumed per unit time. Also, since the feeding time on the larger $G$. polyhedra is not significantly different from the smaller $P$. micans, $P$. pellucidum may not be capable of ingesting all the carbon from the larger prey.

The behavioral components of feeding by Protoperidinium pellucidum measured in this study may help us to understand the differences in functional response (ingestion vs food concentration) observed with diatom and dinoflagellate foods (Fig. 2). For a type I functional response curve (Holling 1959b), as is often found for heterotrophic dinoflagellates feeding individually on phytoplankton cells (e.g. Strom \& Buskey 1993, Buskey et al. 1994; Fig. 2), the maximum ingestion rate should be a function of capture success by the predator for that prey type and the time required to handle and digest that food type. Therefore we would predict lower maximum ingestion rates on food types with lower proportions of successful capture and for food types that require longer handling and ingestion times. The higher maximum ingestion rate on Ditylum brightwellii compared to Prorocentrum micans (Fig. 2) is probably due mainly to higher capture success, since $P$. pellucidum appears to acquire more carbon per unit time when feeding on dinoflagellates. At its maximum ingestion rate, $P$. pellucidum spends more time feeding on $D$. brightwellij than on $P$. micans. Based on the average time required for feeding (Table 3), at maximum ingestion rates $P$. pellucidum spends only $31.4 \%$ of its time consuming $D$. brightwellii to consume ca 
18.7 cells $\mathrm{d}^{-1}$ ) or $12.3 \%$ of its time consuming $P$. micans (3.4 cells $\mathrm{d}^{-1}$ ). P. pellucidum must spend more of its time with unsuccessful feeding interactions with motile dinoflagellate prey. The steepness of the slope of the functional response curve in the region where ingestion increases linearly with food concentration may be determined in part by the distance at which $P$. pellucidum can detect its food (Fig. 8); as expected the slope of the functional response curve with $D$. brightwellii as food is steeper than with P. micans as food (Fig 2). Using Gerritsen \& Strickler's (1977) encounter model, the number of encounters between $P$. pellucidum and $D$. brightwellii or $P$. micans can be predicted at food concentrations that produce maximum ingestion rates. The encounter rate between $P$. pellucidum and $D$. brightwellii would be 0.97 encounters $\mathrm{min}^{-1}$ at $350 \mu \mathrm{g} \mathrm{Cl}^{-1}$ (569 cells $\mathrm{ml}^{-1}$ ); the encounter rate with $P$ micans would be 0.6 encounters $\mathrm{min}^{-1}$ at $830 \mu \mathrm{g} \mathrm{Cl}^{-1}$ ( 360 cells $\mathrm{ml}^{-1}$ ). It seems surprising that feeding rates were encounter limited at encounter rates only slightly lower than these

Protozooplankters such as heterotrophic dinoflagellates play a central role in marine food wcbs by serving as an important link between phytoplankton primary production and higher trophic levels. Although there may be a tendency to consider small, unicellular organisms as lacking in complex sensory capabilities and behavioral adaptations, there is a growing body of evidence that many protozoa have sophisticated behavioral and sensory capabilities and are capable of selectively feeding on specific types of food using criteria other than size. In this study, the ability of a pallium feeding heterotrophic dinoflagellate to feed selectively in mixtures of food has been demonstrated, and the behaviors contributing to this feeding selectivity have been explored. Although feeding selectivity was found not to be a simple function of phytoplankton size, the precise factors affecting prey selection, especially within a single taxonomic group such as the diatoms, remain unknown. Future studies need to examine the chemosensory capabilities of the protozoa in more detail, and to examine the roles of feeding prehistory and adaptation in prey selectivity.

Acknowledgements. This research was supported by NSF Grant OCE 9314036. Technical assistance was provided by Cammie Hyatt, Yaqin Li, Chris Collumb, Scott Stewart and Sara Kowalski. We thank Dennis Weisenburg and the Minerals Management Service for allowing us to participate in the LATEX program cruises. This is University of Texas Marine Science Institute Contribution number 1000.

\section{LITERATURE CITED}

Andrews JC (1983) Deformation of the active space in the low Reynolds number feeding current of calanoid copepods. Can J Fish Aquat Sci 40:1293-1302
Bossert WH, Wilson EO (1963) The analysis of olfactory communication among animals. J Theor Biol 18:157-170

Burkill PH, Edwards ES, John AWG, Slesgh MA (1993) Microzooplankton and their herbivorous activity in the northeastern Atlantic Ocean. Deep Sea Res 40:479-493

Buskey EJ (1984) Swimming pattern as an indicator of the roles of copepod sensory systems in the recognition of food. Mar Biol 79:16.5-175

Buskey EJ, Coulter CJ, Brown SL (1994) Feeding, growth and bioluminescence of the heterotrophic dinoflagellate Protoperidinium huberi. Mar Biol 121:373-380

Buskey EJ, Coulter CJ, Strom SL (1993) Locomotory patterns of microzooplankton: potentual effects on food selectivity of larval físh. Bull Mar Sci 53:29-43

Buskey EJ, Stoecker DK (1989) Behavioral responses of the manne tintinnid Favella sp. to phytoplankton: influence of chemical mechanical and photic stimuli. J Exp Mar Biol Ecol 132:1-16

Buskey EJ, Swift E (1990) An encounter model to predict natural bioluminescence. Limnol Oceanogr 35:1469-1485

Drenner RW, Strickler JR, O'Brien WJ (1978) Capture probability: the role of zooplankter escape in the selective foeding of planktivorous fish. J Fish Res Board Can 35: $1370-1373$

Fenchel T (1986) Protozoan filter feeding. Prog Protistol 1: $65-133$

Fitt WK (1985) Chemosensory responses of the symbiotic dinoflagellate symbiodinum microadriaticum (Dinophyceae). J Phycol 21:62-67

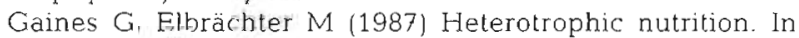
Taylor FJR (ed) The biology of dinoflagellates. Blackwell, Oxford, p 224-268

Gerritsen J, Strickler JR (1977) Encounter probabilities and community structure in zooplankton: a mathematical model. J Fish Res Board Can 34:73-82

Gifford DJ (1985) Laboratory culture of marine planktonic oligotrichs (Ciliophora, Oligotricha). Mar Ecol Prog Ser 23: $257-26$ ?

Greene CH, Landry MR (1985) Patterns of prey selection in the cruising calanoid predator Euchaeta elongata. Ecology 66:1408-1416

Guillard RRL, Ryther RH (1962) Studies of marine planktonic diatoms I. Cyclotella nana Hudstedt and Detonula confervacea (Cleve) Gran. Can J Microbiol 8:229-239

Hansen PJ (1991) Quantitative importance and trophic role of heterotrophic dinoflagellates in a coastal pelagial food web. Mar Ecol Prog Ser 73:253-261

Hansen PJ (1992) Prey size selection, feeding rates and growth dynamics of heterotrophic dinoflagellates with special emphasis on Gyrodinium spirale. Mar Biol 114:327-334

Hauser DCR, Levandowsky M. Hunter SH, Chunosoff L, Hollwitz JS (1975) Chemosensory responses by the heterorophic marine dinoflagellate, Crypthecodinium cohnii Microb Ecol 1:246-254

Heinbokel JF (1978) Studies of the functional role of tintinnids in the Southern Califorma Bight. I. Grazing and growth rates in laboratory cultures. Mar Biol 47:177-189

Holling CS (1959a) The components of predation as revealed by a study of small-mammal predation of the European sawfly. Can Entomol 91:293-320

Holling CS (1959b) Some characteristics of simple types of predation and parasitism. Can Entomol 91:385-398

Holling CS (1966) The functional response of invertebrate predators to prey density. Mem Entomol Soc Can 48:1-86

Jacobson DM. Anderson DM (1986) Thecate heterotrophic dinoflagellates: feeding behavior and mechanisms. J Phy$\operatorname{col} 22: 249-258$ 
Jacobson DM, Anderson DM (1993) Growth and grazing of Protoperidinium hirobis Abé, a thecate heterotrophic dinoflagellate. J Plankton Res 15:723-736

Jeong HJ, Latz MI (1994) Growth and grazing rates of the heterotrophic dinoflagellates Protoperidinium spp. on red tıde dinoflagellates. Mar Ecol Prog Ser 106:173-185

Landry MR (1978) Predatory feeding behavior of a marine copepod, Labidocera trispinosa. Limnol Oceanogr 23: $1103-1113$

Levandowsky M, Cheng T, Kehr A, Kim J, Gardner L, Silvern L. Tsang L, Lai G, Chung C, Prakash E (1984) Chemosensory responses to amino aclds and certain amines by the ciluate Tetrahymena: a flat capillary assay. Biol Bull 167 $322-330$

Moal J, Martin-Jezequel V, Harris RP, Samin JF, Poulet SA (1987) Interspecific and intraspecific variability of the chemical composition of marine phytoplankton. Oceanol Acta 10:339-346

Parsons TR, Stephens K, Strickland JDH (1961) On the chemical composition of eleven species of marine phytoplankters. J Fish Res Board Can 18:1001-1016

Pyke GH, Pulliam HR, Charnov EL (1977) Optimal foraging a selective review of theory and tests. Q Rev Biol 52: $137-154$

This article was presented by D. Stoecker (Semior Editorial Advisor), Cambridge, Maryland, USA
Spero HJ (1985) Chemosensory capabilities in the phagotrophic dinoflagellate Gymnodinium fungiforme. J Phycol $21: 181-184$

Stoecker DK. Guillard RRL, Kavee RM (1981) Selective predation by Favella ehrenbergii (Tintinnida) on and among dinoflagellates. Biol Bull 160:136-145

Strom SL. Buskey EJ (1993) Feeding growth and behavior of the thecate heterotrophic dinoflagellate Oblea rolunda Limnol Oceanogr 38:965-977

Tiselius P, Kuylenstıerna M (1996) Growth and decline of a diatom spring bloom: phytoplankton species composition formation of marine snow and the role of heterotrophic dinoflagellates. J Plankton Res 18:133-155

Verity PG (1988) Chemosensory behavior in marine planktonic ciliates. Bull Mar Sci 43:772-782

Verity PG (1991) Feeding in planktonic protozoans: evidence for non-random acquisition of prey. J Protozool 38:69-76

Verity PG, Stoecker DK, Sieracki ME, Burkill PH. Edwards ES, Tronzo CR (1993) Abundance, biomass and distribution of heterotrophic dinoflagellates during the North Atlantic spring bloom. Deep Sea Res 40:227-244

Verity PG, Villareal TA (1986) The relative food value of diatoms, dinoflagellates, flagellates, and cyanobacteria for tintinnid cliates. Arch Protistenkd 131:71-84

Manuscript first received: January 2, 1997

Revised version accepted: April 28, 1997 